\title{
PRODUCTION OF ALPHA AMYLASE AND CELLULASE FROM SOLID STATE CULTURE OF ASPERGILLUS OCHRACEUS: A FEASIBILITY ANALYSIS
}

\author{
Sohail Khan ${ }^{1}$, Ashwani Mathur ${ }^{{ }^{*}}$ \\ Address (es): \\ ${ }^{1}$ Department of Biotechnology, Jaypee Institute of Information Technology, Noida, A-10, Sector-62, Noida, Uttar Pradesh-201309, India
}

*Corresponding author: ashwani.mathur@jiit.ac.in

https://doi.org/10.36547/ft.321

\section{ABSTRACT}

The growing demand and application of industrially important enzyme necessitate the need to explore new sources with diverse enzymes ranging in their specificity and activities. Enzymes are safe alternatives to chemical synthesis due to minimum side effect and ease of manufacturing. Solid state fermentation (SSF) is a cost-effective alternative to submerged fermentation with agro-residues or waste, often being used as substrate for growing diverse organisms for production of metabolites. Current study is one of the scarce report on exploring alpha amylase and cellulase production ability Aspergillus ochraceus (MTCC 1877) using wheat bran as substrate at relative humidity of $90 \%$ and at $30{ }^{\circ} \mathrm{C}$, for 7 days. Result showed the potential of Aspergillus ochraceus (MTCC 1877), as potential source of the two enzymes. Results revealed comparatively higher alpha amylase activity in the SSF extract of Aspergillus ochraceus (MTCC 1877) in comparison to Trichoderma longibrachiatum (ITCC 7839). On the contrary, comparatively higher cellulase activity was observed in the SSF extract of Trichoderma longibrachiatum (ITCC 7839). The results showed the potential of Aspergillus ochraceus (MTCC 1877) as a source of the two enzymes. Variation in enzymes activity may be attributed to the experimental culture conditions and may be further optimized to enhance the enzymes yield.

Keywords: Enzymes, Solid state, Aspergillus ochraceus, Trichoderma longibrachiatum, cellulase, alpha amylase

\section{INTRODUCTION}

Solid state fermentation (SSF), is a well explored technology, used for production of value-added products, by growing bacterial and fungal strains on solid substrate (or support) with insignificant or no free water. The technique had been used for centuries, for developing fermented food (Hyseni et al., 2018; Pablo et al., 2020). The 'GRAS' strains mediated development of fermented food, feed and pharmaceutical products had been well explored using SSF (Barrios-González et al., 1988; Ramachandran et al., 2004; Sitanggang et al., 2020). Enzymes are one of the most well explored and utilized biomolecules, in various industrially important sectors, and are economically produced using SSF (Pandey et al., 2008; Liu and Kokare, 2017). These biocatalysts are primarily proteins in nature and are produces from diverse range of organisms (Liu and Kokare, 2017). It is this diversity of biomolecules from different sources and their associated properties that obtrude them as a suitable safe alternative to chemical catalysts (Vanacek et al., 2018). It is this diversity in the catalytic properties of enzymes that had been a boon for their application in various commercial sectors ranging from food, feed and pharmaceutics to paper and pulp, jute and textile sectors, environmental remediation, and others (Koyani and Rajput, 2015; Raveendran et al., 2018).

Diversity in the habitats of different microorganisms is associated with the diversity in the reaction conditions variability of the enzyme (Müller et al., 2015; Garcia-Garcera and Rocha, 2020). It is these diversities and wide acceptability of enzymes in different sectors that provide an impetus to explore new or novel organisms as source of enzymes.

The enzyme production from fungal strains on agro-residues as substrate, through SSF had been reported to be higher in yield and cheaper in cost, thereby making the overall process economical (Pandey et al., 2008; Agrawal et al., 2013; Pablo López-Gómez et al., 2020).

Previous studies have shown the vast varieties of enzymes, that can be successfully produced using Aspergillus sp. (Hu et al., 2011; Lopes et al., 2011; Shinkawa and Mitsuzawa, 2020). The fungi, Aspergillus ochraceus is, well known for its mycotoxic effects on plant and chicks owing to the production of secondary metabolite, Ochratoxin A, extensively reported for its hazardious effects (Doupnik, 1970; Hocking, 2006; Martínez-Rodríguez and Santiago, 2011; de Almeida et al., 2019). However, recent interest in A. ochraceus is primarily due to the therapeutic potential of other metabolites from the fungi. Studies by Hu et al., (2021) had shown the anti-Parkinson's effects of alkaloids and other metabolites produced by A. ochraceus. In another study by Aracri $\boldsymbol{e t}$ al., (2019), the potential of A. ochraceus, as a potential source of enzyme Tannase had been reported.
Current study is the first feasibility analysis of the fungal strain, Aspergillus ochraceus MTCC 1877, as a potential source of industrially important enzymes (viz. alpha amylase and cellulase) on agro-residues, using solid state fermentation.

\section{MATERIALS AND METHODS}

\section{Fungal strain and culture media}

The current studies were performed using Aspergillus ochraceus (MTCC 1877), purchased from Microbial Type Culture Collection (MTCC), Institute of Microbial Technology, Chandigarh, India. The fungi Trichoderma longibrachiatum (ITCC 7839), was used to compare the output of SSF among the two fungi. All further studies were performed using the two fungi, under similar experimental conditions. The growth and maintenance of the strain was done using Potato dextrose agar (HiMedia Laboratories Pvt. Ltd., India). The solid-state fermentation studies were performed using wheat bran as substrate. All other chemicals used in the studies were of analytical grade, unless specified.

\section{Growth and maintenance of fungal strain}

The fungi were revived from the cryostocks of fungi, preserved at $-20^{\circ} \mathrm{C}$. Both the fungi, Aspergillus ochraceus (MTCC 1877) and Trichoderma longibrachiatum (ITCC 7839), were revived from the cryostock and propagated on potato dextrose agar (PDA) plate at $30{ }^{\circ} \mathrm{C}$ for 7 days in incubator (Kühner, Switzerland). After revival of the strains, the culture plates were stored at $4{ }^{\circ} \mathrm{C}$.

\section{Solid state fermentation studies}

The humidity is an important component of solid-state fermentation and largely depends on nature of substrate. In current study, the change in relative humidity (RH) with increasing volume of water was measured using Winner Thermo hygrometer TH-402 (Fig. 1). The wheat bran was autoclaved twice at $121{ }^{\circ} \mathrm{C}$ for 30 minutes to reduce the microbial load. The plastic petri plate with $20 \mathrm{~g}$ wheat bran and $\mathrm{RH}$ of $90 \%$ was used for solid state fermentation studies. The plates were inoculated with two cuboidal pieces $(1 \mathrm{~cm} \times 1 \mathrm{~cm}$; length $\times$ width, height depends on thickness of agar plate) each, and the plates were incubated at $30^{\circ} \mathrm{C}$ for 7 days. After the 7 days of culture, the fermented solid materials were harvested in a muslin cloth that was used for enzyme extraction.

\section{Extraction of Enzymes}

The feasibility of SSF harvest as a source of enzymes, alpha amylase and cellulase, were analyzed by suspending $40 \mathrm{~g}$ harvest and tied in muslin cloth, in 
$200 \mathrm{ml}$ distilled water at $270 \mathrm{rpm}, 4{ }^{\circ} \mathrm{C}$ for 2 hours. The liquid extract was used further for enzyme activity.

\section{Enzyme assay for Alpha Amylase}

The activity of $\alpha$-amylase in the extract was analyzed using the alpha amylase assay method reported by Luo et al., (2019), with modification. The assay method involves estimation of reducing sugars, produced on hydrolysis of starch using Dinitrosalicylic acid (DNS) reagent. The reaction mix for prepared by mixing $1 \mathrm{ml}$ of $1 \%(\mathrm{w} / \mathrm{V})$ starch with $1 \mathrm{ml}$ of extract. The reaction mixture was incubated for $10 \mathrm{~min}$. Further $1 \mathrm{ml}$ DNS reagent and $5 \mathrm{ml}$ distilled water was added, and the solution was boiled. The solution was cooled and the absorbance at $540 \mathrm{~nm}$ was monitored. The enzyme activity was defined to be $1 \mathrm{U} / \mathrm{ml}$ when 1 mg of reducing sugar was liberated per unit time, per unit volume of enzyme under optimum conditions of temperature and $\mathrm{pH}$. The quantity of reducing sugar was estimated using the standard plot, prepared using glucose as standard.

\section{Enzyme Activity of Cellulase}

The activity of Cellulase in the extract was estimated using the assay method suggested by Lone et al.,(2012), with some modifications. Briefly, $1 \mathrm{ml}$ of cellulose (1\% microcrystalline in water) was mixed with $1 \mathrm{ml}$ extracted and incubated at room temperature for 10 minutes. The mixture was further supplemented with $1 \mathrm{ml}$ DNS Reagent and $5 \mathrm{ml}$ water. The tubes were placed in boiling water bath at around $80^{\circ} \mathrm{C}-100{ }^{\circ} \mathrm{C}$. The solution was cooled and the absorbance at $540 \mathrm{~nm}$ was monitored. The enzyme activity was defined to be 1 $\mathrm{U} / \mathrm{ml}$ when $1 \mathrm{mg}$ of reducing sugar was liberated per unit time, per unit volume of enzyme under optimum conditions of temperature and $\mathrm{pH}$. The quantity of reducing sugar was estimated using the standard plot, prepared using glucose as standard.

\section{RESULTS AND DISCUSSION}

Cellulase and alpha amylase are widely used in food, feed and pharmaceutical sectors. The vast application of these industrial enzymes, obtrude them as highly demanded enzymes. Current study explored the potential of Aspergillus ochraceus MTCC 1877, as a suitable alternative source of the enzymes. The choice of using Trichoderma longibrachiatum ITCC 7839, in the study, for comparisons of results, was based on previous reports highlighting Trichoderma longibrachiatum to be the source of cellulase (Tegl et al., 2016) and amylase (Kovacs et al., 2004) enzymes. Results showed that the Aspergillus ochraceus MTCC 1877, had the potential of being a source of two industrially important enzymes, viz, cellulase and alpha amylase. The comparative analysis of the results of the two fungi (Figure 1), showed comparatively higher activity of alpha amylase in the extract from Aspergillus ochraceus MTCC 1877. The results suggest the importance of culture conditions in the variation in yield of enzyme among the two fungal strains. Further, the analysis of cellulase activities among the two organisms (Figure 2), revealed the opposite response of two fungi. The cellulase activity after the SSF was observed to be higher in the extract of Trichoderma longibrachiatum ITCC 7839 than Aspergillus ochraceus MTCC 1877.

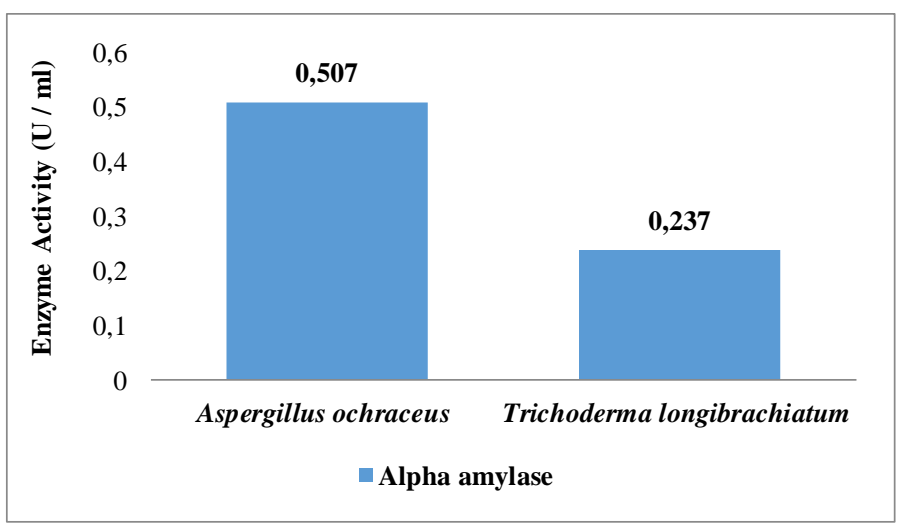

Figure 1 Comparison of the alpha amylase activity (U / ml) of Aspergillus ochraceus and Trichoderma longibrachiatum in solid state fermentation studies

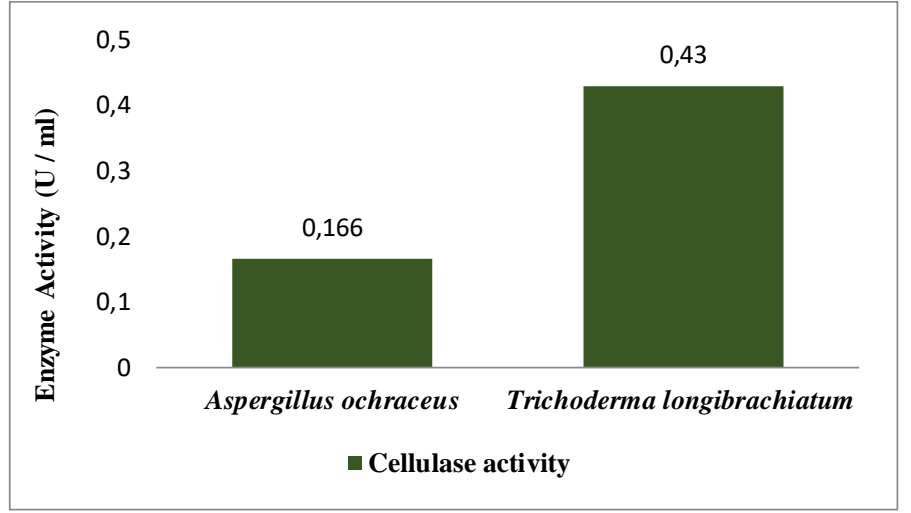

Figure 2 Comparison of the cellulase activity (U / ml) of Aspergillus ochraceus and Trichoderma longibrachiatum in solid state fermentation studies

The role of bioprocess parameters in the growth, metabolism and production of various primary and secondary metabolites from different industrially important organisms have been well explored (Bailey and Ollis, 1986). The organisms can produce both the enzymes. However, difference in enzyme activity of the two strains may be attributed to variation in the microenvironment around the growing fungal strains and their response to abiotic parameters $(90 \% \mathrm{RH}$ in wheat bran at $30{ }^{\circ} \mathrm{C}$ after 7-day culture). The feasibility analysis suggests Aspergillus ochraceus MTCC 1877 to be a potential source of alpha amylase and cellulase.

\section{CONCLUSION}

Aspergillus ochraceus strain had been well explored for its mycotoxic effect and associated mycotoxins. The fungal metabolites had also shown some significant effect against neurological diseases. However, scarce reports are available on their potentials of being a source of enzymes. Current study explored the significance of co-production of alpha amylase and cellulase on the agro-residue, 'wheat bran', under controlled experimental conditions. The study will pave the way for exploration of other commercially important enzymes from the organisms and strategic approach to optimize culture conditions for improving the yield of enzymes.

\section{REFERENCES}

Agrawal R., Satlewal A., Verma A.K. (2013). Production of an extracellular cellobiase in solid state fermentation.Journal of Microbiology, Biotechnology and Food Sciences, 2 (4), 2339-2350.

Aracri F.M., Cavalcanti R.M.F., Guimaraes L.H.S. (2019). Extracellular Tannase from Aspergillus ochraceus: Influence of the Culture Conditions on Biofilm Formation, Enzyme Production, and Application. Journal of Microbiology and Biotechnology, 29(11):1749-1759. https://doi.org/10.4014/jmb.1903.03060

Bailey J., and Ollis D., (1986), In: (eds.), Biochemical Enginering Fundamentals, $2^{\text {nd }}$ Edition, New York: McGrow Hills.

Barrios-González J., Tomasini A., Viniegra-González G., López L. (1988). Penicillin production by solid state fermentation.Biotechnology Letters, 10, 793798. https://doi.org/10.1007/BF01027575

Chakraborty S., Ásgeirsson B., Rao B.J. (2012). A Measure of the Broad Substrate Specificity of Enzymes Based on 'Duplicate' Catalytic Residues. PLoS ONE, 7(11): e49313. https://doi.org/10.1371/journal.pone.0049313

de Almeida Â. B., Corrêa I. P., Furuie J. L., de FariasPires T., do RocioDalzoto P., and Pimentel I. C. (2019). Inhibition of growth and ochratoxinA production in Aspergillus species by fungi isolated from coffee beans. Brazilian journal of microbiology, 50(4), 1091-1098.https://doi.org/10.1007/s42770-019-00152-9

DoupnikJr B., Peckham J. C. (1970). Mycotoxicity of Aspergillus ochraceus to $\begin{array}{llll}\text { chicks. } & \text { Applied } & \text { microbiology, } & \text { 19(4), }\end{array}$ 597.https://doi.org/10.1128/am.19.4.594-597.1970

Garcia-Garcera M., Rocha E.P.C. (2020). Community diversity and habitat structure shape the repertoire of extracellular proteins in bacteria. Nature Communication, 11, 758.https://doi.org/10.1038/s41467-020-14572-x

Hocking A.D. (2006). Aspergillus and related teleomorphs. In: de W. Blackburn C. (ed.), Food Spoilage Microorganisms, Woodhead Publishing Series in Food Science, Technology and Nutrition, Woodhead Publishing, pp 451487.https://doi.org/10.1533/9781845691417.4.451

Hu H.L., van den Brink J., Gruben B.S., Wösten H.A.B., Gu J.-D., de Vries R.P. (2011). Improved enzyme production by co-cultivation of Aspergillusniger and 
Aspergillusoryzae and with other fungi, International Biodeterioration\& Biodegradation, 65 (1), 248-252. https://doi.org/10.1016/j.ibiod.2010.11.008

Hu L., Tian S., Wu R., Tong Z., Jiang W., Hu P., Xiao X., Zhang X., Zhou H., Tong Q., Lu Y., Huang Z., Chen Y., Zhang Y. (2021). Identification of antiParkinson's Disease lead compounds from Aspergillus ochraceus targeting Adenosin receptors A2A. Chemistry Open, 10(6), 630-638. https://doi.org/10.1002/open.202100022

Hyseni B., Aytekin A.Ö., Nikerel E. (2018). Solid state fermentation for enzyme production for food industry.Journal of Microbiology, Biotechnology and Food Sciences, 7 (6), 615-622. https://doi.org/10.15414/jmbfs.2018.7.6.615-622

Kovacs K., Szakacs G., Pusztahelyi T., Pandey A. (2004). Production of chitinolytic enzymes with Trichoderma longibrachiatum IMI 92027 in solid substrate fermentation.Applied Biochemistry and Biotechnology, 118(1-3), 189204. https://doi.org/10.1385/ABAB:118:1-3:189

Koyani R.D., Rajput K.S. (2015). Involvement of extracellular fungal enzymes in bioremediation of textile effluent, Journal of Microbiology, Biotechnology $\begin{array}{llllll}\text { and Food Sciences, } 5 & \text { (5), } & 450 & - & 455 .\end{array}$ https://doi.org/10.15414/jmbfs.2016.5.5.450-455

Liu X., Kokare C. (2017). Microbial Enzymes of Use in Industry, In: Brahmachari G., Demain AL and Adrio JL (eds.). Biotechnology of Microbial Enzymes- production, biocatalysis and industrial applications, Elsevier, Academic Press, London, Vol.11, pp. 267-298. https://doi.org/10.1016/B978-012-803725-6.00011-X

Lone M.A., Wani M.R., BhatN.A., SheikhS.A. ReshiM.A.(2012). Evaluation of cellulase enzyme secreted by some common and stirring rhizospherefungi of Juglansregia L. by DNS method. Journal of Enzyme Research, 3 (1), 18-22.

Lopes F. C., Silva L. A., Tichota D. M., Daroit D. J., Velho R. V., Pereira J. Q., Corrêa A. P., Brandelli A. (2011). Production of Proteolytic Enzymes by a Keratin-Degrading Aspergillusniger. Enzyme research, 2011, 487093.https://doi.org/10.4061/2011/487093

Luo K., Kim N. G., You S. M., Kim Y. R. (2019). Colorimetric Determination of the Activity of Starch-Debranching Enzyme via Modified Tollens'

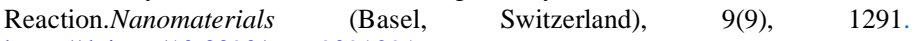
https://doi.org/10.3390/nano9091291

Martínez-Rodríguez A.J., Santiago A.V.C. (2011). Application of the Hazard Analysis and Critical Control Point System to Winemaking: Ochratoxin A. In: Carrascosa A.V., Muñoz R., González R. (eds.), Molecular Wine Microbiology, Academic Press, pp. 319-339.https://doi.org/10.1016/B978-0-12-375021$\underline{1.10013-X}$

Müller A.L., Kjeldsen K.U., Rattei T., Pester M., Loy A. (2015). Phylogenetic and environmental diversity of DsrAB-type dissimilatory (bi)sulfitereductases. The ISME Journal, 9(5), 1152-1165. https://doi.org/10.1038/ismej.2014.208

Pablo López-Gómez J., Manan M.A., Webb C. (2020). Solid-state fermentation of food industry wastes, In:Kosseva M.R., Webb C., (eds.), Food Industry Wastes (Second Edition), Academic Press, 2020, pp 135-161. https://doi.org/10.1016/B978-0-12-817121-9.00007-3

Pandey A., Soccol C.R., and Lorroche C. (2008). General consideration about solid state fermentation process, In: (eds.), Current Developments in Solid-state Fermentation, Springer, Asiatech Publisher Inc., India , pp. 13-25. https://doi.org/10.1007/978-0-387-75213-6_2

Ramachandran S., Patel K.A., Nampoothiri K.M., Francis F., Nagy V., Szakacs G., Pandey A. (2004). Coconut oil cake - a potential raw material for the production of $\alpha$-amylase. Bioresource Technology, 2004, 93, 169-174. https://doi.org/10.1016/j.biortech.2003.10.021

Raveendran S., Parameswaran B., Ummalyma S.B., Abraham A., Mathew A.K., Madhavan A., Rebello S., Pandey A. (2018). Applications of Microbial Enzymes in Food Industry, Food Technology and Biotechnology, 56(1), 16-30. https://doi.org/10.17113/ftb.56.01.18.5491

Shinkawa S., Mitsuzawa S. (2020).Feasibility study of on-site solid-state enzyme production by Aspergillusoryzae.Biotechnology for Biofuels, 13, 1-15. https://doi.org/10.1186/s13068-020-1669-3

Sitanggang A.B., Sinaga W.S.L., Wie F., Fernando F., Krusong W. (2020). Enhanced antioxidant activity of okara through solid state fermentation of GRAS Fungi.Food Science and Technology, 40 (1), 178 - 186. https://doi.org/10.1590/fst.37218

Tegl G., Öhlknecht C., Vielnascher R., Kosma P., Hofinger-Horvath A., Guebitz G.M. (2016). Commercial cellulases from Trichoderma longibrachiatum enable a large-scale production of chito-oligosaccharides, Pure and Applied Chemistry, 88 (9), 865-872. https://doi.org/10.1515/pac-2016-0703

Vanacek P., Sebestova E., Babkova P., Bidmanova S., Daniel L., Dvorak P., Stepankova V., Chaloupkova R., Brezovsky J., Prokop Z., Damborsky J.(2018).Exploration of enzyme diversity by integrating bioinformatics with expression analysis and biochemical characterization, ACS Catalysis, 8 (3), 2402-2412.https://doi.org/10.1021/acscatal.7b03523 